\title{
BILINGUALISM IN LATVIAN AND RUSSIAN IN THE CONTEXT OF DEMOGRAPHIC PROCESSES IN LATVIA
}

\author{
Vineta Porina \\ University of Latvia
}

\begin{abstract}
This article deals with Latvian becoming the dominant language in Latvia. The results of the study show that the proportion of Latvians increased from $52 \%$ in 1989 to $57.7 \%$ in 2000 and to $59.3 \%$ in 2009 . The percentage of the entire population who are speakers of Latvian increased from $61.7 \%$ in 1989 to $79 \%$ in 2000 and $93 \%$ in 2008 (Latvijas 2000. gada tautskaites rezultāti 2002, Valoda 2008). Since regaining independence, many positive changes regarding the de facto functioning of Latvian have taken place in Latvia e.g. the proportion of non-Latvians purporting to possess good knowledge of Latvian increased 10-15\% between 2000 and 2008, whilst a similar decrease is registered for those whose knowledge of Latvian is weak. The most dramatic increase in Latvian speakers is in the 15-34 age group, which must be attributed to bilingual education; Latvian is becoming a more frequent tool of communication between Latvians and ethnic minorities. At present, the favourable conditions for the strengthening of the state language are contrary to common world practice.
\end{abstract}

Keywords: individual and social bilingualism, state language, etnodemographic processes, functional bilinguals, self-assessment of bilingualism, language use

\section{Introduction}

Individual bilingualism in research may be bracketed with social bilingualism, since components of individual bilingualism (such as the proficiency level of an individual's second language and the motivation to communicate in a second language) affect the development of social bilingualism. On the other hand, components of social bilingualism (such as the prestige of the other language in a particular social group and the need to command and use a certain language) affect the attitude of the respective 
group of individuals towards the second language and its learning. A study of correlation of individual and social bilingualism provides the theoretical basis necessary for corrective measures to be adapted in a non-viable language situation and prognoses to be made of the ethno-political situation in the country in order to promote its stability and security.

In Latvia, app. 1.4 million inhabitants have a good command of Latvian and use it regularly. Thus Latvian is one of the $5 \%$ of languages in the world whose speakers number more than one million. The results of this study show that the proportion of Latvians increased from $52 \%$ in 1989 to $57.7 \%$ in 2000 and to $59.3 \%$ in 2009 . The proportion of speakers of the total population who have a knowledge of Latvian increased from $61.7 \%$ in 1989 to $79 \%$ in 2000 and $93 \%$ in 2008 (Latvijas 2000. gada tautskaites rezultāti 2002, Valoda 2008). This would appear to augur well for the future of Latvian if it were not for the de facto situation with respect to the use of the state language. Due to the relatively small population of Latvia, migration processes exert a greater effect on its make-up than in countries with larger populations. In this context, monolingualism functioning in groupings with Russian as a common language, the discrepancy between proficiency in and use of Latvian by people from minorities in the public space, the radically different information spread by mass media, (especially the press) in Latvian and Russian and the relatively recent introduction of English as a language factor in society make for deficiencies in state legislation in coping with the difficult language situation and guarantee that Latvian remains a world language.

\section{The ethnodemographic situation in Latvia}

In 2009 the population of Latvia numbered 2,261,294 inhabitants (cf. 2,377,383 in 2000 and 2,667,000 in 1989). This reveals a decrease of $15.2 \%$ in the population since 1989 . Some 150 nationalities were registered in the census of 2000 and app. 175 in 2008. In 2009 the nation comprised 59.3\% ethnic Latvians (57.7\% in 2000) and $40.7 \%$ ethnic minorities (42.3\% in 2000). The proportional distributions of the larger minorities of the population in 1989, 2000 and 2009 are given in Table 1. 
Table 1. Number and percentage of largest ethnicities of total population (Latvijas 2000. gada tautas skaitīšanas rezultāti 2002: 13, Demogrāfija 2009: 35)

\begin{tabular}{|l|r|r|r|r|r|r|}
\hline \multirow{2}{*}{ Ethnicity } & \multicolumn{2}{|c|}{1989} & \multicolumn{2}{c|}{2000} & \multicolumn{2}{|c|}{2009} \\
\cline { 2 - 7 } & Number & \multicolumn{1}{c|}{$\%$} & Number & \multicolumn{1}{c|}{$\%$} & Number & \multicolumn{1}{c|}{$\%$} \\
\hline $\begin{array}{l}\text { All popula- } \\
\text { tion }\end{array}$ & 2666567 & 100.0 & 2377383 & 100.0 & 2261294 & 100.0 \\
\hline Latvians & 1387757 & 52.0 & 1370703 & 57.7 & 1340143 & 59.3 \\
\hline Russians & 905515 & 34.0 & 703243 & 29.6 & 628535 & 27.8 \\
\hline Belarusians & 119702 & 4.5 & 97150 & 4.1 & 81862 & 3.6 \\
\hline Ukrainians & 92101 & 3.5 & 63644 & 2.7 & 56183 & 2.5 \\
\hline Poles & 60416 & 2.3 & 59505 & 2.5 & 53177 & 2.4 \\
\hline Lithuanians & 34630 & 1.3 & 33430 & 1.4 & 30415 & 1.3 \\
\hline Jews & 22897 & 0.9 & 10385 & 0.4 & 9915 & 0.4 \\
\hline Roma & 7044 & 0.3 & 8205 & 0.3 & 8570 & 0.4 \\
\hline Germans & 3783 & 0.1 & 3465 & 0.1 & 4500 & 0.2 \\
\hline Estonians & 3312 & 0.1 & 2652 & 0.1 & 2480 & 0.1 \\
\hline
\end{tabular}

Between 1989 and 2000, the proportion of Poles and Lithuanians increased, but that of Russians, Belarusians, Ukrainians and Jews decreased. The proportion of Roma, Germans and Estonians did not change from 1989 to 2000. Since 2000, however, the proportion of Roma and Germans has increased. The proportion of Estonians and Jews has remained unchanged. With respect to the only autochthonous minority - the Livs - the registered number of persons was small (178), yet they and Roma are the only Latvian ethnoses who registered a natural increase, although statistically insignificant (Livs 1 , Roma 66). With respect to the employment age of inhabitants, a disturbing factor is that the non-employment age groups exceeded the employment age group by $6.4 \%$. This is one of the most important determinants 
of the long-term language situation if we take into account the stimulus of economic emigration from Latvia, which in turn has a bearing on the language situation.

The percentage decrease registered in the largest minorities living in Latvia between 1898 and 2009 was accompanied by an increase in the proportion of Latvians in 2009 by $7.3 \%$ (in 2000 the increase was 5.7\%). However, numerically there were 30500 fewer Latvians in 2009 than in 2000. This is due to the low birth rate and the wave of emigration. For example, in 2009, the net migration of Latvians during the first eight months was -999 and -1524 in 2008 (most of them Latvians who had registered their residence outside of Latvia). Thus, although the proportion of Latvians in the country has shown an upward trend, a relatively low proportion of the titular nation and a significant representation of people of other nationalities with respect to the total population remains a characteristic feature of Latvia.

In general, the ethnodemographic structure of the population of Latvia favours Latvians: in comparison with the data from 1989 and 2009, we can see that the proportion of Latvians, in contrast to other ethnic groups in the country, has grown somewhat over the last 20 years to reach $59.3 \%$ in $2009(52.0 \%$ in 1989). Despite this, the language situation remains too fragile to safeguard Latvians as the titular nation and ensure the development of the Latvian language. In the major cities of Latvia, Latvians are often outnumbered by groupings with Russian as the common language e.g. in 2009 in Daugavpils (the second largest city in the country) there were just $17.5 \%$ Latvians, in Riga $42.3 \%$ and in Liepaja $52.76 \%$.

The data from the study New Baltic Barometer carried out by Richard Rose (Rose 2000) showed that under the given circumstances, app. $12 \%$ of Latvian and $23 \%$ of Russian respondents would choose to emigrate; in other words, Latvians were prepared to leave Latvia to a lesser degree. However, since the beginning of the $21^{\text {st }}$ century, emigration has increased greatly, mainly due to economic factors, and Latvians are as willing as minority representatives to leave the country. This is a major threat to the demographic balance of Latvia.

Recent years have witnessed an increase in the identity awareness of ethnic groups with respect to their native languages (i.e. those other than Latvian or Russian): the study Valoda (Language) (Valoda 2008: 54) shows that $97 \%$ of Latvians con- 
sider Latvian their native language, and 3\% Russian; 98.7\% of Russians consider Russian their native language, $0.7 \%$ Latvian and $0.6 \%$ other languages; $13.8 \%$ of ethnic minorities consider Latvian their native language, $43.6 \%$ Russian and $42.6 \%$ other languages.

\section{Functional bilingualism and the model of bilingualism in Latvia}

The main criteria for individual bilingualism are the following: the distribution of individual bilingualism in the population; the functional activity of both languages (i.e. the degree of active use of each of the languages); and the level of skills of the other language. There are several significant aspects that should be taken into account in studies of individual bilingualism. The most important distinction is the distinction between language skills and language use. Sociolinguistic terminology is insufficiently nuanced and to precisely define the border between the proficiency level of the two languages of a bilingual individual and the use of these languages in practice. To quote from W. F. Mackey's article A Terminology for Sociolinguistic: "A science that can tolerate more than three dozen definitions of "culture", two dozen definitions of "ethnicity" and a score of definitions of "primitive" is still a long way from rating as a unified field of knowledge." (Mackey 1990: 103-104) There is a tendency to refer to individual bilingualism as the functional use of the other language, whereas the present situation in many parts of the world requires a focus on societies where speakers of different languages come into contact, and on how these contacts affect the sociolinguistic functions of each of the languages.

There are two opposing schools of thought in the field of bilingualism. Adherents of the narrow definition: a bilingual individual is a person fluent in two (or more) languages; and those of the broader definition: everyone is bilingual (Edwards 1994: 55). Leonard Bloomfield modified the narrow definition: "Active, completely equal mastery of two or more languages" (quoted from Haugen 1987: 14) to "native-like control of two or more languages." Haugen, however, thinks that this is an ideal, theoretical model: few, if any, actually achieve it (Haugen 1987: 14). 
W. Mackey has categorically stated: "Bilingualism is not a linguistic phenomenon; it characterises the use of language. Bilingualism is not a code, but a feature of a report. It does not belong to a lingua (the language) area, but to the parole (speech) area." (Mackey 1968: 557) Thus, according to Mackey's statement, individual bilingualism is the use of two languages. Understanding of bilingualism has to be adapted to a particular language situation and its needs. In my opinion, Mackey's statement that individual bilingualism is a regular use of two languages (Mackey 1968: 557) could be applied to the existing situation in Latvia (Porina 2001: 142, Porina 2009: 54) and to address the needs required of monolingual minorities: the functional use of the state language in the official space (place of employment, local governments, public services etc.) and minority native language use among families, in cultural activities and in primary education.

\section{Self-assessment of proficiency in the second language}

A bilingual individual's attitude towards a particular language and their assessment of their proficiency in the language are related and subjective factors. Self-assessment of language proficiency is a problematic area of study. It has been observed that assessment of one's own language proficiency and objectively measured language proficiency usually do not match: a self-assessed evaluation tends to be higher than one arrived at through objective measurement. Self-assessment is affected by a person's attitude towards a given language, the status of this language in a social context, social pressure and personality traits. Answers in tests may reflect a fair opinion of language skills or be affected by social expectation. For example, a Russian may profess to having a higher level of proficiency in Latvian than is the case, because in Latvia there is social pressure for other nationalities to know the official language, and also because some Russians have relatively high self-esteem compared to Latvians. T. Skutnabb-Kangas has noted a similar situation with Finns and Swedes (Skutnabb-Kangas 2000: 199): the self-assessment of Swedes in Finland of their Finnish language skills is less credible than the self-assessment of Finns of their skills in Swedish. 
To analyse Latvian and Russian language use in Latvia, the focus here is placed on the sociolinguistic functions of the official language and the common language of many of the minorities i.e. in the areas of communication in which each language is usedeveryday life, at school, in the place of employment etc. - as well as on the impact of the ongoing social processes on an individual's skills in and use of two or more languages. From the answers in the questionnaires of the Valoda study conducted by the Institute of Baltic Social Sciences in 2008 and 2000, the results indicated an increase in knowledge of Latvian: $40 \%$ of minorities $(28 \%$ in 2000 ) said that they could read freely, while $38.3 \%$ (20\% in 2000) considered themselves able to speak the language freely; with respect to writing, the percentage was $29 \%$ (19\% in 2000).

According to the Valoda data, in 2008, 26.2\% of respondents whose native language was not Latvian assessed their Latvian language skills as excellent (in 2000, 13\% of such respondents assessed their Latvian skills as very good); $31.2 \%$ as medium (28\% in 2000); and 35.6\% as weak (50\% in 2000); $7 \%$ had no knowledge of Latvian at all (9\% in 2000).

However, approximately $63 \%$ (30\% in 2000) of respondents indicated that they did not wish to improve their Latvian language proficiency: $43.8 \%(35 \%$ in 2000$)$ thought that they managed well enough; $26.2 \%$ (38\% in 2000) believed that they were too old to learn the language; and $14.7 \%$ (13\% in 2000) felt that they did not need Latvian language skills. Consequently, a number of minority representatives consider they can still do without knowledge of the state language or have no wish to improve their ability to communicate in Latvian, which means that people are willing to live in Latvia without participating in the civil and social processes of the country. The Valoda study in 2008 showed that the proportion $(63 \%)$ of respondents whose native language is not Latvian and who do not wish to improve their Latvian language skills had reached its highest level since 1996. In all groups, the proportion of respondents who were unwilling to improve their Latvian language skills exceeded the proportion of those who wished to do so. In general, from these responses it can be concluded that proficiency at the lowest and medium level in the official language is adequate to ensure daily communication for people of other nationalities.

The data from the study shows that minority women in general are much more willing to integrate into Latvian society 
than men. One reason for this may be that women are more flexible in their thinking than men or that they consider that their offspring will need Latvian in the future (Porina 2000: 291). In 2008 , the answers to the question "Do you want to improve your Latvian language skills?" showed that $41.3 \%$ of women and $31.9 \%$ of men would like to do so. The education system seems to be quite successful in that proficiency in Latvian at both the social and individual levels of minorities in the 15-34 age group has exceeded other age groups (see Table 2). Figures show that since 2000, the proportion of those who do not understand the language or speak it poorly has decreased, while the proportion of those who can speak it at an intermediate level or manage very well has increased (Table 2 and 3 ).

Table 2. Self-assessment of Latvian language skills of minority respondents in percentages (Valoda 2000: 55, Valoda 2008: 63)

\begin{tabular}{|c|r|r|r|r|r|r|r|r|}
\hline \multirow{2}{*}{$\begin{array}{c}\text { Age } \\
\text { group }\end{array}$} & \multicolumn{2}{|c|}{$\begin{array}{c}\text { Do not know } \\
\text { language }\end{array}$} & \multicolumn{2}{c|}{$\begin{array}{c}\text { Level 1 } \\
\text { (low) }\end{array}$} & \multicolumn{2}{c|}{$\begin{array}{c}\text { Level 2 } \\
\text { (average) }\end{array}$} & \multicolumn{2}{c|}{$\begin{array}{c}\text { Level 3 } \\
\text { (high) }\end{array}$} \\
\cline { 2 - 9 } & 2000 & 2008 & 2000 & 2008 & 2000 & 2008 & 2000 & 2008 \\
\hline $15-34$ & 3.5 & 1.4 & 46.8 & 25.7 & 33.2 & 39.1 & 16.5 & 33.7 \\
\hline $35-49$ & 4.2 & 8.0 & 49.0 & 37.9 & 35.8 & 35.2 & 10.9 & 19.0 \\
\hline $50-74$ & 19.4 & 10.2 & 53.0 & 40.9 & 16.8 & 23.3 & 10.7 & 25.6 \\
\hline
\end{tabular}

Table 3. Self-assessment of fluency in Latvian of minority respondents in percentages (Valoda 2000: 55-58, Valoda 2008: 63-66)

\begin{tabular}{|c|c|c|c|c|c|c|c|c|}
\hline $\begin{array}{c}\text { Age } \\
\text { group }\end{array}$ & \multicolumn{2}{|c|}{$\begin{array}{c}\text { Know } \\
\text { language } \\
\text { fluently }\end{array}$} & \multicolumn{2}{c|}{$\begin{array}{c}\text { Speak } \\
\text { fluently }\end{array}$} & \multicolumn{2}{c|}{$\begin{array}{c}\text { Read } \\
\text { fluently }\end{array}$} & \multicolumn{2}{c|}{$\begin{array}{c}\text { Write } \\
\text { fluently }\end{array}$} \\
\cline { 2 - 10 } & 2000 & 2008 & 2000 & 2008 & 2000 & 2008 & 2000 & 2008 \\
\hline $15-34$ & 16.5 & 33.7 & 24.3 & 48.7 & 38.6 & 51.6 & 22.4 & 38.0 \\
\hline $35-49$ & 10.9 & 19.0 & 18.0 & 33.2 & 29.4 & 33.5 & 19.0 & 21.8 \\
\hline $50-74$ & 10.7 & 25.6 & 17.3 & 34.4 & 18.0 & 36.9 & 15.1 & 29.4 \\
\hline
\end{tabular}


This data may be compared to the answers of Latvian respondents with respect to their Russian language skills (Table 4). Obviously, the proportion of Latvian respondents who do not know Russian compared to the proportion of minority respondents who do not know Latvian is small in all age groups, but in general, the proficiency level of Latvians in Russian is higher than the level of Latvian language proficiency among other nationalities. In all age groups, the proportion of Latvian respondents who can speak Russian very well has decreased. As a result of the everyday use of Russian, previous education and the language environment, the proficiency level in Russian of respondents in the 35-75 age group has not decreased.

Table 4. Self-assessment of Russian language skills of Latvians in percentages (Valoda 2000: 59, Valoda 2008: 67)

\begin{tabular}{|c|r|r|r|r|r|r|r|r|}
\hline $\begin{array}{c}\text { Age } \\
\text { group }\end{array}$ & \multicolumn{2}{|c|}{$\begin{array}{l}\text { Do not know } \\
\text { the language }\end{array}$} & \multicolumn{2}{|c|}{$\begin{array}{l}\text { Know at a } \\
\text { low level }\end{array}$} & \multicolumn{2}{|c|}{$\begin{array}{c}\text { Know at an } \\
\text { average level }\end{array}$} & \multicolumn{2}{|c|}{$\begin{array}{c}\text { Know very } \\
\text { well }\end{array}$} \\
\cline { 2 - 9 } & 2000 & 2008 & 2000 & 2008 & 2000 & 2008 & 2000 & 2008 \\
\hline $15-34$ & 1.0 & 8.4 & 17.2 & 37.7 & 33.6 & 29.0 & 48.1 & 24.8 \\
\hline $35-49$ & 0.0 & 1.3 & 5.6 & 13.6 & 23.9 & 39.4 & 70.5 & 45.7 \\
\hline $50-74$ & 5.6 & 2.5 & 18.5 & 19.4 & 24.4 & 30.6 & 51.5 & 47.5 \\
\hline
\end{tabular}

On comparing proficiency in the second language at the higher levels of Latvian and minority respondents between 2000 and 2008 (Table 4), it is apparent that the proportion of those Latvians with Russian language skills at the highest level has significantly decreased, but during these years perceptible changes have taken place: the proportion of minority respondents whose Latvian language proficiency is at the highest level has doubled in all age groups since 2000. In general the level of Latvian language proficiency is low. This is one indicator showing a shift in the dominant language at the individual level (Table 5). 
Table 5. Self-assessment with respect to high language proficiency in second language (Valoda 2000: 58-59, Valoda 2008: 63, 67)

\begin{tabular}{|c|c|c|c|c|}
\hline \multirow{2}{*}{$\begin{array}{c}\text { Age } \\
\text { group }\end{array}$} & $\begin{array}{c}\text { High level Russian language } \\
\text { skills among Latvian re- } \\
\text { spondents, \% }\end{array}$ & $\begin{array}{c}\text { High level Latvian language } \\
\text { skills among minority re- } \\
\text { spondents, \% }\end{array}$ \\
\cline { 2 - 5 } & 2000 & 2008 & 2000 & 2008 \\
\hline $15-34$ & 48.1 & 24.8 & 16.5 & 33.7 \\
\hline $35-49$ & 70.0 & 45.7 & 10.9 & 19.0 \\
\hline $50-74$ & 51.5 & 47.5 & 10.7 & 25.6 \\
\hline
\end{tabular}

\section{Functions of Latvian and Russian language use in sociolinguistic domains $(2000 \& 2008)$}

Latvian and Russian language use at home, at work, in communication with friends, in public places, on the street, in shops etc. was investigated in the Valoda study in which respondents answered questions about the language(s) they spoke in various situations.

Responses showed that in 2008, at home, where the language used was indicative of the individual's belonging to a linguistic group, 91\% (92\% in 2000) of Latvian respondents spoke mostly or only Latvian; Latvian rather than Russian was spoken by $6 \%$ ( $4 \%$ in 2000); Russian rather than Latvian by $2 \%$ ( $2 \%$ in 2008); and mainly or only Russian by $1 \%$ (2\% in 2000$)$. $69.1 \%$ of minority respondents (84\% in 2000) spoke mostly or exclusively Russian at home; Russian rather than Latvian was used by $16.9 \%$ (12\% in 2000); Latvian rather than Russian by $5.2 \%(2 \%$ in 2000$)$; and another language was spoken mainly or exclusively by $4.9 \%$ (1\% in 2000). Assessing the data surveyed, assimilation of minorities with respect to language cannot be seen, since Latvian was used at home by app. 5\% of ethnic minorities, which is only slightly more than 8 years earlier. Nevertheless, figures show that the percentage of respondents who speak mostly or only Russian at home is decreasing.

At work, mainly or only Latvian was spoken by $57.2 \%$ (71\% in 2000) of Latvian respondents; more often Latvian than 
Russian by 36\% (21\% in 2000); more often Russian than Latvian by $5.4 \%$ ( $5 \%$ in 2000$)$; mainly or only Russian by $0.5 \%$ (2\% in 2000 ); and mainly or exclusively in another language by $0.9 \%$ (1\% in 2000). With respect to minority respondents, mainly or solely Russian was spoken by $27.9 \%$ (41\% in 2000); more Russian than Latvian by $38.5 \%$ (35\% in 2000); more often Latvian than Russian by $25.7 \%$ (16\% in 2000); mainly or only Latvian by $6.2 \%(7 \%$ in 2000$)$; and mainly or exclusively another language by $1.7 \%$ (1\% in 2000$)$. Thus, in general, Latvian is used more often than Russian in places of employment. Since 2000, however, the use of Latvian by Latvians has decreased, as has the use of Russian by minorities.

In communication with friends and acquaintances, mainly or only Latvian was spoken by $67.1 \%$ (71\% in 2000) of Latvian respondents; more often Latvian than Russian by $28.4 \%$ (24\% in 2000); more Russian than Latvian by $4.1 \%$ (4\% in 2000); and mainly or only Russian by $0.3 \%$ (1\% in 2000$)$. $49.5 \%$ of minority respondents (98\% in 2000) used mainly or only Russian and $2.5 \%$ (2\% in 2000) mainly or only Latvian. The fact that Russian language use has decreased among ethnic minorities in communication with their friends and acquaintances can be explained either by the fact that Russians are being absorbed into Latvian groupings or that there is a notable shift towards choosing friends and acquaintances according to their linguistic affiliation.

In public places, such as streets and shops, mainly or only Latvian was spoken by $65.3 \%$ (74\% in 2000) of Latvian respondents; more often Latvian than Russian was spoken by $30.8 \%$ ( $24 \%$ in 2000); more Russian than Latvian by 3.3\% (2\% in 2000); mainly or only Russian by $0.5 \%$ (1\% in 2000$)$; and mainly or exclusively another language registered $0 \%(1 \%$ in 2000). This in turn points to bilingual communication in Latvian and Russian in public places rather than multilingual communication. $40.2 \%$ of minority respondents (42\% in 2000) in the street and shops spoke in Russian more frequently than in Latvian; $31.1 \%$ (35\% in 2000) mainly or exclusively in Russian; in both 2000 and 2008, 18\% used more Latvian than Russian; and 7.7\% (5\% in 2000) spoke mainly or solely in Latvian. Thus, in streets and shops, more than $70 \%$ of minority respondents used Russian most often, which means that minority respondents regard public places as a monolingual Russian domain. 


\section{Conclusions}

Analysis of the data presented demonstrates that the increasing individual bilingualism in their native language and Latvian among minority representatives is not a significant contributing factor in a shift towards the dominance of the state language in Latvia. Since proficiency in Latvian has increased in minorities living in Latvia, Latvian is chosen more often for communication with Latvians than previously. However, Russian is the language chosen between ethnic Latvians and minorities in language choice situations. Thus, the high level of individual bilingualism in the state has not yet led to a change establishing Latvian as the dominant language.

In countries where the official language is the language of the titular nation, functional monolingualism among this nation is considered to be the norm (for example, in Germany, France and Sweden). In Latvia, where the official language is also the language of the titular nation, bilingualism of both this nation and the collective language of the minorities has become the norm. In the Latvian language situation, the most relevant fact is not how many ethnic minorities speak Latvian, but rather whether it is commonplace in everyday communication. Extralinguistic factors such as civic consciousness and awareness, the self-awareness of the titular nation, domestic political and economical processes in the country, ethno-linguistic identification and the process of social integration of minorities play an important role. Currently, the backdrop of political relations with Russia exerts an influence on the use of Latvian by minorities, as does the media in Russian: the media space at present is far more divided than in the mid-1990s.

A non-typical situation in bilingualism theory and practice is due to the difficult economic conditions in Latvia that reduce national problems such as immigration and the conditions for immigration to pragmatism rather than national policy with regard to labour and employment. This situation facilitates institutions in regarding the language situation and language-related activities as matters of secondary importance. A non-typical situation in bilingualism theory, unemployment, promotes the willingness of other nationalities to pass the official language test, and this results in a growing level of minority bilingualism and the role of the Latvian language in the country: the language environment is being optimised. The unattractive economic conditions in Latvia compared to other European countries is the reason why, due 
to emigration of other nationalities, Latvia is becoming more Latvian - the percentage of Latvians is growing in the country every year. But the decrease in Russian language skills among the Latvian linguistic group is promoting the development of a more Latvian environment, and in language choice situations Latvian is having to be chosen more than before, for example between younger generations of Latvians with representatives of minorities. This fact is contradictory if we consider any language as the individual's linguistic capital, but in Latvia, unfortunately, Russian as linguistic capital contributes to the asymmetric bilingualism of Latvians, because it is often used for communication between Latvians and other nationalities.

Significant changes are expected, not only due to increasing economic dependence on large neighbouring countries, huge waves of emigration and the background of political relationships with Russia, but also due to global processes - the continuous division of political and economic spheres and the constantly increasing concentration of capital and competition between world religions. As a result, serious legal, linguistic and educational support for Latvian as the single official language of the state is becoming more important than ever before.

Address:

Vineta Porina

Martas Str. 1-8

Riga LV 1011

Latvia

E-mail: Vineta.Porina@latnet.lv

\section{References}

Baker, Colins (1996) Foundations of bilingual education and bilingualism. 2nd ed. Clevedon, Philadelphia, and Adelaide: Multilingual Matters Ltd.

Demogrāfija 2009 (2009) Statistisko datu krājums. Rīga: LR Centrālā statistikas pārvalde.

Edwards, John (1994) Multilingualism. London, New York: Routledge.

Haugen, Einar (1987) Blessings of Babel. Bilingualism and language planning: problems and pleasures. Berlin, New York, and Amsterdam: Mouton de Gruyter. 
Latvijas 2000. gada tautas skaitī̌̌anas rezultāti. Statistikas datu krājums (2002).

Rīga: Latvijas Republikas. Centrālā statistikas pārvalde.

Mackey, William F. (1968) “The description of bilingualism”. In Joshua Fishman, ed. Readings in the sociology of language, 555-584. Paris: Mouton.

Mackey, William F. (1990) "A terminology for sociolinguistics". Sociolinguistics 19, 99-124.

Poriņa. Vineta (2000) “Indivīda un sabiedrības multilingvisms Latvijā: situācija un prognozes” In E. Vēbers, red. Integrācija un etnopolitika, 282-297. Rīga: Jumava.

Poriņa, Vineta (2001) "Bilingvisms Latvijā individuālajā un sabiedrības aspektā". LZA Vēstis 55, 5-6, 140-143.

Poringa, Vineta (2009) Valsts valoda daudzvalodīgajā sabiedrībā: individuālais un sociālais bilingvisms Latvijā. Rīga: Latviešu valodas institūts.

Rose, Richard (2000) New Baltic barometer IV: a survey study. Glasgow: University of Strathclyde, The Centre of Public Policy.

Skutnabb-Kangas, Tove (2000) Linguistic genocide in education-or worldwide diversity and human rights? Mahwah: Lawrence Erlbaum Associates.

Valoda (2000) Latvijas iedzīvotāju aptauja. Aprīlis-maijs 2000. Rīga: Baltijas Sociālo Zinātņu institūts.

Valoda (2008) Latvijas iedzīvotāju aptauja. Marts-aprīlis 2008. Rīga: Baltijas Sociālo Zinātņu institūts.

\section{Kokkuvõte. Vineta Poriņa: Läti ja vene kakskeelsusest demograafi-} liste protsesside kontekstis Lätis. Artikli keskmes on läti keel, millest on saanud dominantkeel Lätis. Uurimuse tulemused näitavad, et lätlaste osakaal rahvastikus on kasvanud 52\%-lt (1989. a) 57,57\%-ni 2000. aastal ning 59,3\%-ni 2009. aastal (Latvijas 2000. gada tautskaites rezultāti 2002, Valoda 2008). Läti keele rääkijate protsent rahvastikus on aga kasvanud 61,7\%-lt (1989. a) 79\%-ni 2000. aastal ning 93\%-ni 2008. aastal. Alates Läti taasiseseisvumise ajast on Lätis aset leidnud mitmed positiivsed muutused läti keele de facto funktsioneerimise suhtes: näiteks mittelätlaste osakaal, kes soovivad omandada läti keele hea oskuse, on ajavahemikul 2000-2008 suurenenud 10-15\% võrra, samal määral on täheldatud läti keele nõrga oskuse vähenemist. Kõige hüppelisem suurenemine on läti keele rääkijate hulgas toimunud vanuserühmas 15-34, mida võib seostada kakskeelse haridusega (bilingual education). Läti keelt on hakatud rohkem kasutama ka lätlaste ning vähemuste vahelises suhtluses.

Võtmesõnad: individuaalne, ühiskondlik kakskeelsus, riigikeel, demograafilised protsessid, funktsionaalsed kakskeelsed, enesehindamine kakskeelsuse suhtes, keele kasutamine 